\title{
Faktor-Faktor yang Mempengaruhi Produksi Usahatani Jagung di Desa Tesi Ayofanu Kecamatan Kie Kabupaten Timor Tengah Selatan
}

Yuliana Bantaika $\mathrm{a}^{\mathrm{a}}$

${ }^{a}$ Fakultas Pertanian, Universitas Timor, Kefamenanu, Indonesia.

\section{Article Info}

\section{Article history:}

Received 8 November 2016

Received in revised form 14 November 2016 Accepted 7 Januari 2017

Keywords:

Faktor Produksi

Usahatani

Jagung

\section{Abstrak}

Penelitian ini berujuan untuk mengetahui gambaran usahatani jagung, dan faktor-faktor yang mempengaruhi usahatani jagung. Metode analisis data yang digunakan adalah analasis deskriptif kualitatif dan model analis data Cobb-Douglas. Hasil penelitian menunjukkan usahatani jagung di desa Tesi Ayofanu dimulai dari persiapan lahan, persiapan benih, penanaman, penyiangan, panen, pasca panen dan penyimpanan. Pada uji f semua faktor yang diuji secara bersama-sama berpengaruh terhadap produksi usahatani jagung. Sedangkan pada uji t atau secara parsial variabel yang berpengaruh terhadap produksi usahatani jagung yaitu luas lahan dan benih sedangkan variabel tenaga kerja, pengalaman dan pendidikan tidak berpengaruh terhadap produksi usahatani jagung. Nilai koefisien determinasi sebesar sebesar $88,5 \%$ terhadap produksi usahatani jagung, sisanya sebesar $11,5 \%$ dipengaruhi oleh faktor lain yang tidak diteliti dalam penelitian ini. (C)2017 dipublikasikan oleh Agrimor.

\section{Pendahuluan}

Pembangunan sektor pertanian merupakan bagian yang sangat penting bag perekonomian Indonesia. Peranan sektor pertanian antara lain meningkatkan pendapatan dan taraf hidup petani dan nelayan, memperluas lapangan kerja dan kesempatan usaha, serta mengisi dan memperluas pasar, baik pasar dalam neger maupun pasar luar negeri. Salah satu sektor pertanian yang cukup strategis adalah sub sektor tanaman pangan. Subsektor tanaman pangan semakin signifikan posisinya manakala dikaitkan dengan isu ketahanan pangan, baik pada skala rumah tangga maupun wilayah. Ketersediaan pangan yang cukup dan disertai kemudahan masyarakat untuk mendapatkannya akan menjamin terwujudnya upaya pencapaian dan peningkatan ketahanan pangan (Cahyadinata dan Sukiyono, 2008).

Jagung merupakan salah satu komoditi tanaman pangan yang potensia untuk dikembangkan karena merupakan sumber utama karbohidrat dan protein Jagung menjadi salah satu komoditas pertanian yang sangat dan saling terkai dengan industri besar. Selain untuk dikonsumsi untuk sayuran, buah jagung juga bisa diolah menjadi aneka makan. Selain itu, pipilan keringnya dimanfaatkan untuk pakan ternak. Nilai kalori pada jagung mempunyai keunggulan bila dibandingkan dengan beras, Karena jagung mengandung asam lemak esensial yang sangat bermanfaat bagi pencegahan penyakit pembulu darah, (Warisno, 2007).

Kandungan zat gizi jagung per 100 gram antara lain Energi $129 \mathrm{kcal}$, protein 4,1 g, lemak 1,3 g, karbohidrat 30,3 g, kalsium $5 \mathrm{mg}$, fosfor $108 \mathrm{mg}$, besi $1,1 \mathrm{mg}$ vitamin A $117 \mathrm{SI}$, vitamin B 0,18 mg, vitamin C $9 \mathrm{mg}$ dan air 63,5 g, $(\mathrm{Gz}, 2013)$ Dimana semua zat yang terkandung dapat bermanfaat bagi kesehatan tubuh manusia dan jugadapat mencegah beberapa penyakit.

Tabel 1. Data Produksi dan Luas Panen di Kecamatan Kie Tahun 2010-2014

\begin{tabular}{cccc}
\hline No & Tahun & Produksi (Ton) & Luas Panen (Ha ) \\
\hline 1 & 2010 & 2,429 & 1,812 \\
2 & 2011 & 4,144 & 1,480 \\
3 & 2012 & 9,293 & 3,319 \\
4 & 2013 & 12,692 & 4,533 \\
5 & 2014 & 12,681 & 12,681 \\
\hline \multicolumn{5}{l}{ Sumber: Dinas Pertanian Tanaman Pangan Kabupaten Timot Tengah Selatan, 2014. }
\end{tabular}

Menurut data dari Badan Pusat Statistik Kabupaten Timor Tengah Selatan produksi Jagung mengalami peningkatan selama tiga tahun terakhir sehingga pada tahun 2011 produksi jagung sebesar 524.000 ton, tahun 2012 sebesar 625.000 ton, dan tahun 2013 sebesar 101.000 ton, (BPS Kab. TTS, 2014)

Kecamatan Kie merupakan salah satu kecamatan yang ada di Kabupaten Timor Tengah Selatan. Kecamatan ini terdiri dari 13 desa yakni Desa fatu ulun, Desa Tesi Ayofanu, Desa Belle, Desa Nekmese, Desa Boti, Desa Oinlasi, Desa Napi, Desa Falas, Desa Eno Napi, Desa Oenai, Desa Naileu, Desa Pili dan diantara ke 13 desa tersebut terdapat salah satu desa yang memiliki produks jagung yang sangat tinggi yaitu Desa Tesi Ayofanu, (BPS Kab. TTS, 2014).

Tabel 2. Data Produksi, Luas Tanam dan Luas Panen di Desa Tesi Ayofanu Tahun 2011-2015.

\begin{tabular}{ccccc}
\hline No & Tahun & Produksi (Ton) & Luas Tanam $(\mathrm{Ha})$ & Luas Panen $(\mathrm{Ha})$ \\
\hline 1 & 2011 & 587 & 19,5 & 16,5 \\
2 & 2012 & 587 & 19,5 & 16,5 \\
3 & 2013 & 587 & 19,5 & 16,5 \\
4 & 2014 & 587 & 19,5 & 16,5 \\
5 & 2015 & 587 & 19,5 & 16,5 \\
\hline
\end{tabular}

Sumber: Desa Tesi Ayofanu, 2015.

Tabel 1. menunjukan bahwa produksi jagung di Kecamatan Kie dari tahun 2010-2014 mengalami peningkatan. Tabel 2. juga menunjukan bahwa produksi jagung di Desa Tesi Aiyofanu dari tahun 2011-2015 mengalami peningkatan yang sama. Hal inilah yang memotivasi penulis untuk melakukan penelitian tentang "Faktor-Faktor yang Mempengaruhi Produksi Usahatani Jagung di Kecamatan Kie Desa Tesi Aiyofanu Kabupaten Timor Tengah Selatan.

\section{Metode}

Penelitian dilaksanakan di Desa Tesi Aiyofanu, Kecamatan Kie, Kabupaten Timor Tengah Selatan. Teknik pengambilan sampel dalam penelitian menggunakan teknik simple random sampling dengan total sampel 53 orang. Data yang digunakan yaitu data primer dan data sekunder. Variabel yang digunakan dalam penelitian ini yaitu luas lahan, benih, tenaga kerja, pengalaman dan pendidikan. Untuk mengetahui gambaran usahatani jagung digunakan analisis deskriptif kualitatif sesuai petunjuk Nasir, (2003), sedangkan untuk mengetahui faktor-faktor produksi yang mempengaruhi produksi usahatani jagung digunakan analisis regresi berganda dalam bentuk fungsi produksi Cobbdouglas sesuai petunjuk Soekartawi, (1990). Data primer yang diperoleh dari hasil wawancara dengan responden diolah dengan menggunakan bantuan software SPSS 16.0.

\section{Hasil dan Pembahasan}

\subsection{Gambaran Usahatani Jagung}

Budidaya jagung yang dilakukan oleh petani Desa Tesi Ayofanu kecamatan kie biasanya dilakukan pada awal musim hujan dan jenis jagung yan dibudidayakan adalah jenis jagung lokal putih. Dan pada umumnya jenis jagung yang dibudidaayakan di desa Tesi Ayofanu pada umumnya dilakukan dengan sistem tumpangsari dengan tanaman semusim lainnya seperti labu, kacang tali, kacang gude(turis), kacang hijau, kacang tanah, kacang merah ubi jalar, dan ub kayu. Teknik budidaya jagung yang dilakukan oleh petani atau responden dimulai dari kegiatan persiapan lahan sampai pada panen dan pasca panen.

a. Persiapan lahan dan pengolahan lahan

Persiapan lahan dan pengolahan lahan biasanya dilakukan pada musim kemarau yaitu bulan agustus - oktober. Persiapan lahan yang dilakukan dilokas penelitian yaitu: dengan cara sistem tebas bakar yaitu untuk membuka lahan yang baru dengan menggunkan parang, setelah itu petani mengolah kembali lahan yang lama dengan cara tanah dibalik menggunakan pacul atau linggis dengan tujuan untuk menggemburkan tanah sehingga tanaman jagung dapat tumbuh dengan baik.

b. Persipan benih

Persiapan benih yang dilakukan oleh masyarakat Tesi Ayofanu yaitu pertama-tama jagung diluruh, setelah diluruh pisahkan biji jagung yang baik untuk ditanam dan biji jagung yang dipisahkan sebagai benih yaitu biji jagung yang dipanen pada tahun lalu.

c. Penanaman

Penanaman dilakukan pada awal saat musim turunnya hujan yaitu berkisar antara bulan November-desember. Kegiatan penanaman jagung di lokasi penelitian secara tradisional yakni setiap lubang tanam diisi lebih dari 2 jenis tanaman seperti jagung, labu, kacang tali , kacang gude (turis), kacang tanah, kacang merah, kacang hijau, ubi kayu dan ubi jalar. Jagung ditanam dengan jarak $75 \times 25 \mathrm{~cm}$ menggunakan lingis setiap lubang tanam diisi 3-4 biji jagung kemudian ditutup dengan tanah.

d. Penyiangan

Penyiangan dilakukan oleh petani 1-2 kali tergantung dari kondisi gulma Penyiangan pada tanaman jagung dapat dilakukan apabila tanaman itu sudah berumur 5-6 helai daun. Kegiatan penyiangan dimaksudkan untuk menekan pertumbuhan tanaman gulma dan tanaman jagung bersaing dalam unsur hara Alat-alat yang digunakan saat menyiang yaitu : tofa dan pacul . Tenaga kerja yang digunakan untuk kegiatan penyiangan adalah tenaga kerja dari dalam keluarga.

e. Panen

Pemanenan di lakukan setelah tanaman jagung mencapai umur panen yaitu 3-4 bulan setelah tanam. pemanenan dilakukan apabila jagung sudah tua dan bila kulit jagung sudah kuning dan mengering dan Pemanenan yang dilakukan dilokasi penelitian biasanya dilakukan dengan cara manual yaitu jagung dipatah 
lalu dikumpulkan dan disusun didalam karung dan hasil jagung yang sudah dipanen di bawah ke rumah.

f. Pasca Panen

Penanganan pasca panen biasa dilakukan dengan cara pengeringan, pada umumnya dilakukan dengan menghamparkan jagung disinar matahari menggunakan tikar atau terpal, pada waktu matahari cerah penjemuran dilakukan selama 3-4 hari.

g. Penyimpanan

Setelah selesai dijemur jagung disimpan dalam rumah bulat sehingga dilakukan pengasapan agar jagung dapat disimpan lebih lama dan tidak mudah rusak.

\subsection{Analis Cobb-Douglas}

Analisis yang digunakan dalam penelitian ini adalah analisis regrersi berganda dalam bentuk logaritma dengan fungsi produksi Cobb-Douglas. Model matematis fungsi produksi dengan metode ordinary least square (OLS). Fungsi Cobb-Douglas digunakan untuk menguji pengaruh antara variebel independen terhadap produksi jagung. Dari angka korelasi pada tabel kemudian dilakukan model pendugaan dengan cara regresi yang hasilnya disajikan pada Tabel 3.

Tabel 3. Analisis Varians

\begin{tabular}{lccccc}
\hline \multirow{2}{*}{\multicolumn{1}{c}{ Variebel }} & \multicolumn{2}{c}{ Koefisien Bebas } & $\begin{array}{c}\text { Koefisien } \\
\text { Baku }\end{array}$ & \multirow{2}{*}{$\mathrm{T}$} & Sig \\
\cline { 2 - 4 } & $\mathrm{B}$ & Std.Eror & Beta & & \\
\hline (Constant) & 4.399 & .849 & & 5.179 & .000 \\
Luas lahan (X1) & .121 & .581 & .138 & 2.208 & .836 \\
Benih (X2) & .675 & .548 & .771 & 2.420 & .224 \\
Tenaga Kerja (X3) & .042 & .160 & .034 & 0.261 & .795 \\
Pengalaman (X4) & .059 & .063 & .049 & 0.935 & .355 \\
Pendidikan (X5) & -.014 & .115 & -.007 & -0.124 & .902 \\
\hline
\end{tabular}

Sumber: Data Primer Diolah, 2016

Dari Tabel 3. diketahui bahwa hasil dari fungsi Cobb-douglas adalah $Y=\ln$ $4.399+0,138 \ln _{\mathrm{x} 1}+0,771 \ln _{\mathrm{x} 2+} 0,034 \ln _{\mathrm{x} 1}+0,049 \ln _{\mathrm{x} 4}-0,007 \ln _{\mathrm{x} 5}$

\subsection{Uji F}

Uji F dilakukan untuk mengetahui variebel-variebel (luas lahan, benih, tenaga kerja, pengalaman, dan pendidikan) secara bersama-sama mempengaruhi produksi usahatani jagung dengan membandingkan rata-rata regresi dengan ratarata kuadrat residu, hasilnya dapat dilihat dalam Tabel 4. Secara sersempak (bersama-sama) variabel luas lahan, benih, jumlah tenaga, pengalaman, dan pendidikan memiliki pengaruh yang signifikan terhadp produksi usahatani jagung. Hal ini dapat ditunjukkan dari nilai $\mathrm{f}_{\text {hitung }}$ lebih besar dari $\mathrm{f}_{\text {tabel }}(72.637>$ 2,57).

Tabel 4. Analisis $\mathrm{F}_{\text {hitung }}$

\begin{tabular}{lccccc}
\hline \multicolumn{1}{c}{ Model } & $\begin{array}{c}\text { Jumlah } \\
\text { Kuadrat }\end{array}$ & Df & $\begin{array}{c}\text { Jumlah } \\
\text { Rerata }\end{array}$ & $F_{\text {hitung }}$ & $F_{\text {tabel }}$ \\
\hline Regresion & 10.656 & 5 & 2.131 & 72.637 & $2,41(5 \%)$ \\
Residual & 1.379 & 47 & .029 & & \\
Total & 12.035 & 52 & & & \\
\hline
\end{tabular}

Sumber: Data Primer Diolah, 2016

\subsection{Uji t}

Pengaruh dari variabel-variabel bebas terhadap produksi jagung disajikan pada Tabel 5 .

Tabel 5. Analisis $\mathrm{T}_{\text {hitung }}$

\begin{tabular}{|c|c|c|c|c|c|}
\hline \multirow{2}{*}{ Variebel } & \multicolumn{2}{|c|}{ Koefisien Bebas } & \multirow{2}{*}{$\begin{array}{c}\begin{array}{c}\text { Koefisien } \\
\text { Baku }\end{array} \\
\text { Beta }\end{array}$} & \multirow{2}{*}{ T hitung } & \multirow{2}{*}{$\begin{array}{c}\text { T Table } \\
(5 \%)\end{array}$} \\
\hline & B & Std.Eror & & & \\
\hline (Constant) & 4.399 & .849 & & 5.179 & 1.67 \\
\hline Luas lahan (X) & .121 & .581 & .138 & 2.802 & \\
\hline Benih (X2) & .675 & .548 & .771 & 2.420 & \\
\hline Tenaga Kerja (X3) & .042 & .160 & .034 & 0,261 & \\
\hline Pengalaman (X4) & .059 & .063 & .049 & 0,935 & \\
\hline Pendidikan (X5) & -.014 & .115 & -.007 & $-0,124$ & \\
\hline
\end{tabular}

Sumber: Data Primer Diolah, 2016

\section{a. Luas Lahan (X1)}

Berdasarkan hasil perhitungan diatas t hitung $(2.802)>$ dari $t$ tabel $(1,67)$, oleh karena itu dapat dikatakan secara parsial adanya pengaruh luas lahan terhadap faktor produksi. Luas lahan pada daerah penelitian cukup luas berkisar antara 50 are -2 ha sehingga mempengaruhi produksi usahatani jagung. Artinya ketika luas lahan ditambah 1 are akan meningkatkan produksi sebesar 0,121 satuan.

b. Benih (X2)

Berdasarkan hasil perhitungan diatas $t$ hitung $(2,420)>$ dari $t$ tabel $(1,67)$ oleh karena itu dapat dikatakan faktor benih memiliki pengaruh terhadap produksi usahatani jagung. Namun dalam penambahan benih harus disesuaikan dengan kondisi lahan yang ada. Artinya ketika benih ditambah akan meningkatkan produksi sebesar 0.675 satuan.

\section{c. Tenaga kerja}

Berdasarkan hasil perhitungan diatas $t$ hitung $(0,261)<$ dari $t$ tabel $(1,67)$, dapat dikatakan tidak adanya pengaruh tenaga kerja terhadap produksi uasahatan jagung. Hal ini berarti kurangnya tenaga kerja dalam berusahatani jagung sehingga mempengaruhi produksi uasahatani jagung. Ketika terjadi penambahan 1 input satuan akan menigkatkan produksi sebesar 0.042 satuan.

d. Pengalaman (X4)

Berdasarkan hasil perhitungan diatas thitung $(0,935)<$ dari t tabel $(1,67)$, dapat dikatakan tidak adanya pengaruh pengalaman terhadap produksi uasahatani jagung. Di duga kurangnya pengalaman responden dalam berusahatani jagung sehingga mempengaruhi produksi usahatani jagung. Artinya ketika terjadi penambahan 1 satuan input pada pengalaman maka akan meningkatkan produksi sebesar 0.059 satuan.

e. Pendidikan (X5)

Berdasarkan hasil perhitungan diatas t hitung $(-0,124)<$ dari t tabel $(1,67)$, pada taraf singnifikansi $5 \%$, dapat dikatakan pendidikan memiliki pengaruh yang negatif terhadap produksi usahatani jagung. Pendidikan petani diukur berdasarkan jenjang pendidikan yang ditempuh oleh petani, pada daerah penelitian tingkat pendidikan petani terbanyak pada tingkat SD kemudian diikuti tingkat SMP dan SMA. Pendidikan berpengaruh negatif karena dalam pendidikan, petani hanya mempelajari ilmu pengetahuan umum dan tidak mempelajari tentang bagaimana cara budidaya jagung. Artinya ketika pendidikan bertambah akan menyebabkan pengurangan produksi sebesar 0.014 .

\subsection{Koefisien Determinasi $\left(\mathbf{R}^{2}\right)$}

Koefisien determinasi adalah besarnya variebel terikat $(\mathrm{Y})$ yang mampu dijelaskan oleh seluruh variebel bebas (X) dalam model nilai koefisien determinasi merupakan perbandingan antara jumlah kuadrat regresi dengan kuadrat total dapat dilihat pada Tabel 6. Faktor luas lahan, benih, tenaga kerja, pengalaman dan pendidikan memiliki pengaruh sebesar 88,5\% terhadap produksi usahatani jagung, sisanya sebesar 11,5 dipengaruhi oleh faktor lain yang tidak diteliti dalam penelitian ini.

\section{Tabel 6. $\mathrm{R}^{2}$ (Koefisien Determinasi)}

\begin{tabular}{ccccc}
\hline Model & $\mathrm{R}$ & R Square & $\begin{array}{c}\text { Adjusted } \\
\text { R Square }\end{array}$ & $\begin{array}{c}\text { Std. Error of } \\
\text { the Estimate }\end{array}$ \\
\hline 1 & $.941^{\mathrm{a}}$ & .885 & .873 & .17129 \\
\hline Sumber: Data Primer Diolah, 2016 & &
\end{tabular}

\section{Simpulan}

Usahatani Jagung di Desa Tesi Ayofanu dimulai dari 1) Persiapan lahan dan pengolahan lahan; 2) Persiapan benih; 3) Penanaman; 4) Penyiangan; 5) Panen 6) Pasca panen, dan; 7) Penyimpanan. Secara simultan dengan menggunakan uji f pada tingkat kepercayaan $5 \%$ yaitu $\mathrm{f}_{\text {hitung }}>\mathrm{f}_{\text {tabel }} 72,637>2,57$ bahwa variebel luas lahan, benih, tenaga kerja, pengalaman dan pendidikan berpengaruh secara nyata. Sedangkan secara parsial variabel yang berpengaruh nyata yaitu luas lahan dan benih pada taraf kepercayaan $5 \%$. Sedangkan yang tidak berpengaruh nyata yaitu tenaga kerja, pengalaman dan pendidikan.

\section{Pustaka}

BPS Kab. TTS, 2014. Timor Tengah Selatan dalam Angka. Badan Pusat Statistik Kabupaten TTS, So'e.

Cahyadinata, I., Sukiyono, K., 2008. Partisipasi Pasar Petani Jagung danEfeknya terhadap Marketed Surplus Jagung di Kabupaten Seluma Propinsi Bengkulu.

Desa Tesi Ayofanu, 2015. Data Produksi, Luas Tanam dan Luas Panen di Desa Tesi Ayofanu Tahun 2011-2015.

Dinas Pertanian Tanaman Pangan Kabupaten Timot Tengah Selatan, 2014. Data Produksi dan Luas Panen di Kecamatan Kie Tahun 2010-2014.

Gz, F.R., S., 2013. The Miracle of Vegetables. AgroMedia.

Nasir, N., 2003. Metode Penelitian. Ghalia Indonesia, Jakarta.

Soekartawi, 1990. Teori Ekonomi Produksi dengan Pokok Bahasan Analisis Fungsi Cobb-Douglas. Rajawali.

Warisno, 2007. Budi Daya Jagung Hibrida. Kanisius, Yogyakarta. 